\title{
Alveolar Fluid Clearance in Pathologically Relevant Conditions: In Vitro and In Vivo Models of Acute Respiratory Distress Syndrome
}

\author{
Laura A. Huppert ${ }^{1}$ and Michael A. Matthay ${ }^{2 *}$ \\ ${ }^{1}$ Department of Medicine, University of California, San Francisco, CA, USA, ${ }^{2}$ Departments of Medicine and Anesthesia, \\ UCSF School of Medicine, Cardiovascular Research Institute, San Francisco, CA, USA
}

\section{OPEN ACCESS}

Edited by:

Rudolf Lucas,

Augusta University, USA

Reviewed by:

Perenlei Enkhbaatar,

University of Texas Medical Branch,

USA

Dan Predescu,

Rush University, USA

Bethany B. Moore,

University of Michigan, USA

${ }^{*}$ Correspondence:

Michael A. Matthay

michael.matthay@ucsf.edu

Specialty section: This article was submitted to Inflammation,

a section of the journal

Frontiers in Immunology

Received: 09 February 2017

Accepted: 15 March 2017

Published: 07 April 2017

Citation:

Huppert LA and Matthay MA (2017)

Alveolar Fluid Clearance in

Pathologically Relevant Conditions:

In Vitro and In Vivo Models of Acute

Respiratory Distress Syndrome.

Front. Immunol. 8:371.

doi: 10.3389/fimmu.2017.00371
Critically ill patients with respiratory failure from acute respiratory distress syndrome (ARDS) have reduced ability to clear alveolar edema fluid. This reduction in alveolar fluid clearance (AFC) contributes to the morbidity and mortality in ARDS. Thus, it is important to understand why AFC is reduced in ARDS in order to design targeted therapies. In this review, we highlight experiments that have advanced our understanding of ARDS pathogenesis, with particular reference to the alveolar epithelium. First, we review how vectorial ion transport drives the clearance of alveolar edema fluid in the uninjured lung. Next, we describe how alveolar edema fluid is less effectively cleared in lungs affected by ARDS and describe selected in vitro and in vivo experiments that have elucidated some of the molecular mechanisms responsible for the reduced AFC. Finally, we describe one potential therapy that targets this pathway: bone marrow-derived mesenchymal stem (stromal) cells (MSCs). Based on preclinical studies, MSCs enhance AFC and promote the resolution of pulmonary edema and thus may offer a promising cell-based therapy for ARDS.

Keywords: acute respiratory distress syndrome, alveolar fluid clearance, mesenchymal stem (stromal) cells, pulmonary edema, vectorial ion transport

\section{INTRODUCTION}

Pulmonary edema is the abnormal accumulation of fluid in the interstitium and air spaces of the lungs, which leads to impaired gas exchange and respiratory failure. Pulmonary edema can develop from increased pulmonary vascular pressure from left heart failure (cardiogenic pulmonary edema) (1) or from lung parenchymal damage from increased endothelial and epithelial permeability (noncardiogenic pulmonary edema) (2). In both cases, the mechanism for the resolution of alveolar edema is the same: active ion transport across the alveolar epithelium creates an osmotic gradient that drives alveolar fluid clearance (AFC) (3). In the presence of acute lung endothelial and epithelial injury, there is complexity in describing the forces responsible for lung fluid clearance, meaning removal of edema from the lung itself. Net AFC does depend on an intact epithelial barrier that can transport ions from the apical to the basolateral surface and create a mini-osmotic gradient for alveolar fluid absorption. If transvascular fluid flux is increased across lung endothelium from increased pressure or increased permeability, then the rate of AFC will be reduced. Also, net lung fluid clearance will be less. Lung lymphatics do remove edema fluid in either hydrostatic or increased 
permeability lung edema, but they cannot entirely compensate for an increase in transvascular fluid flux or impaired AFC.

Acute respiratory distress syndrome (ARDS) is a syndrome of acute respiratory failure caused by non-cardiogenic pulmonary edema. The most common cause of ARDS is bacterial or viral pneumonia (4). Sepsis due to non-pulmonary sources, trauma, aspiration, pancreatitis, transfusion reactions, and drug reactions can also lead to ARDS (4). Criteria for the diagnosis of ARDS have changed over time, but the current definition includes arterial hypoxemia with $\mathrm{PaO}_{2} / \mathrm{FiO}_{2}$ ratio less than $300 \mathrm{mmHg}$, bilateral radiographic opacities, without evidence of that is not fully explained by cardiac failure or fluid overload (5). The mortality of ARDS is approximately $25-40 \%$ (6), and treatment remains primarily supportive with lung protective ventilation and a fluid conservative strategy (7).

Because ARDS has a broad clinical phenotype, it has been challenging to translate cell and animal studies to pharmacologic therapies that reduce human morbidity and mortality. Nonetheless, in vitro and in vivo studies have produced important insights about the pathogenesis of this condition, paving the way for targeted therapeutics. This review will focus on: (1) mechanisms that mediate the clearance of pulmonary edema in the uninjured lung, (2) why AFC is reduced in ARDS, resulting in the accumulation of pulmonary edema fluid, and (3) one potential treatment for ARDS with a cell-based therapy that may accelerate the rate of $\mathrm{AFC}$.

\section{PULMONARY EDEMA FLUID CLEARANCE IN THE UNINJURED LUNG}

Before discussing AFC in ARDS, it is first important to review how pulmonary edema fluid is cleared in the uninjured lung. In the uninjured lung, vectorial ion transport across the alveolar epithelial cells creates an osmotic gradient that drives fluid from the airspaces into the lung interstitum (Figure 1). It was initially thought that alveolar epithelial type II cells were the primary cell responsible for vectorial ion transport, but subsequent studies demonstrated an important role for type I cells as well (8). The transport of sodium ions is the most important driver for the generation of the osmotic gradient: sodium is transported through the sodium channel $(\mathrm{ENaC})$ on the apical surface and then by the $\mathrm{Na} / \mathrm{K}$ ATPase on the basolateral surface into the lung microcirculation $(9,10)$. Knockout of the alpha-subunit of $\mathrm{ENaC}$ in mice resulted in the inability to remove lung fluid at birth with subsequent respiratory failure and death (9). In addition, non-selective cation channels, cyclic nucleotide-gated channels, and the cystic fibrosis transmembrane conductance regulator chloride channel also contribute to the creation of the osmotic gradient $(3,11)$. Aquaporins facilitate the movement of water across the epithelial surface, but are not required for fluid transport (12).

This system of active ion-driven alveolar fluid reabsorption is the primary mechanism that removes alveolar edema fluid under both physiologic and pathological conditions (9, 13, 14). However, in the setting of ARDS, the capacity to remove alveolar edema fluid is reduced, which is termed impaired AFC. A reduction in the rate of AFC in ARDS correlates with decreased

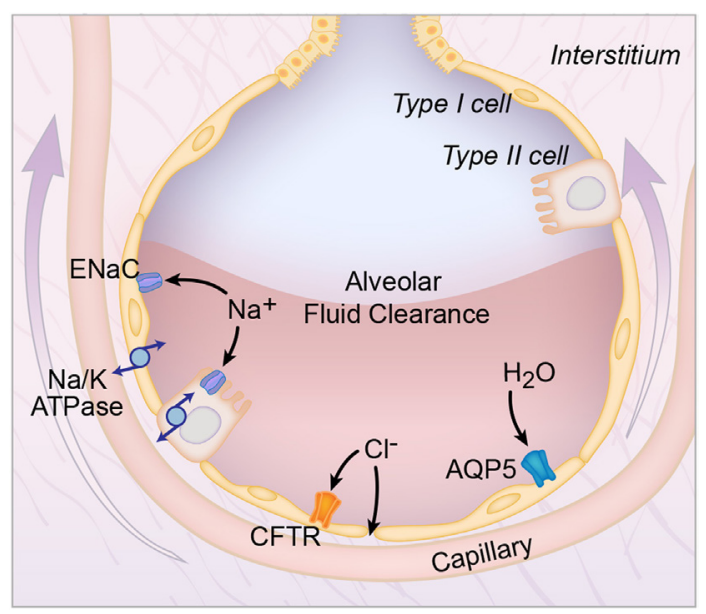

FIGURE 1 Alveolar fluid clearance pathways. Shown are the interstitial, capillary, and alveolar compartments, with pulmonary edema fluid in the alveolus. Both type I (yellow) and type II (orange) alveolar cells are involved in transepithelial ion transport. Sodium $\left(\mathrm{Na}^{+}\right)$is transported across the apical side of the type I and type II cells through the epithelial sodium channel (ENaC), and then across the basolateral side via the sodium/potassium ATPase pump (Na/K-ATPase). Chloride $\left(\mathrm{Cl}^{-}\right)$is transported via the cystic fibrosis transmembrane conductance regulator (CFTR) channel or by a paracellular route. Additional cation channels also transport ions across the alveolar epithelium (not shown). This vectorial ion transport creates an osmotic gradient that drives the clearance of fluid. Specifically, water $\left(\mathrm{H}_{2} \mathrm{O}\right)$ moves down the osmotic gradient through aquaporin channels, such as aquaporin 5 (AQP5) or via an intracellular route (not shown).

survival $(15,16)$. Therefore, it is critical to better understand why AFC is reduced in ARDS to better understand the pathogenesis of this condition.

\section{PULMONARY EDEMA FLUID CLEARANCE IN ARDS}

Multiple mechanisms explain why AFC is reduced in ARDS. First, both hypoxia and hypercapnia impair AFC. ENaC transcription and trafficking is downregulated and $\mathrm{Na} / \mathrm{K}$-ATPase functions less efficiently under states of low oxygen or high carbon dioxide, in part, because reactive oxygen species trigger endocytosis and cell necrosis (17-19). Therefore, supplemental oxygen and correction of hypercapnia can enhance the resolution of alveolar edema (17).

Second, biomechanical stress can reduce AFC. High tidal volumes and elevated airway pressures injure the alveolar epithelium, inducing cell death and inflammation, which reduces AFC (20). If pulmonary hydrostatic pressures are elevated, the rate of AFC is also reduced. These findings help explain the success of lung protective ventilation strategies and conservative fluid strategies in reducing the morbidity and mortality of $\operatorname{ARDS}(21,22)$.

Third, ARDS pulmonary edema fluid contains high levels of pro-inflammatory cytokines including IL- $1 \beta$, IL- $8, \mathrm{TNF} \alpha$, and TGF $\beta 1$ (23-25). Under controlled conditions, this inflammatory response is important for pathogen clearance. However, when excessive levels of cytokines are present, they instead can cause 
alveolar injury and decreased AFC (26-29). Moreover, once the epithelial barrier is breeched and alveolar fluid is released, components of the alveolar fluid may be recognized to induce downstream inflammatory and immune responses (30). There are no current therapies that directly target this pathway in the treatment of ARDS, although lung protective ventilation itself reduces pro-inflammatory cytokines such as IL-6 and IL-8 (4, 31). The remainder of this review will summarize our current understanding of alveolar ion transport in ARDS based on pathologically relevant in vitro and in vivo models, and discuss one potential new therapy that targets this pathway.

In 2006, Fang et al. developed a model of a polarized human alveolar type II cell that facilitated in vitro studies of AFC (32) (Figure 2). Using this model, Lee et al. found that transepithelial fluid transport is less effective in the presence of ARDS edema fluid and found that there are increased levels of cytokines and decreased levels of ion transport proteins in the presence of ARDS edema fluid compared to a plasma control (33). These data support the hypothesis that cytokine expression is increased in alveolar epithelium during ARDS, resulting in a decreased expression of alveolar ion channels and accumulation of alveolar edema fluid. In addition, the inflammatory edema fluid can also cause alveolar cell injury and necrosis, resulting in altered epithelial tight junctions $(34,35)$. The loss of tight junctions can negate the osmotic gradient, offsetting the effects of vectorial ion transport.

Subsequent in vivo studies expanded upon these findings and demonstrated that net AFC was reduced under clinically relevant pathologic conditions in animal models. In sheep, live Pseudomonas aeruginosa decreased AFC at both 4 and $24 \mathrm{~h}$, an effect, which was associated with decreased AFC (36). In a mouse model of influenza pneumonia, the authors demonstrated that there was decreased AFC due to inhibition of the $\mathrm{ENaC}$ epithelial

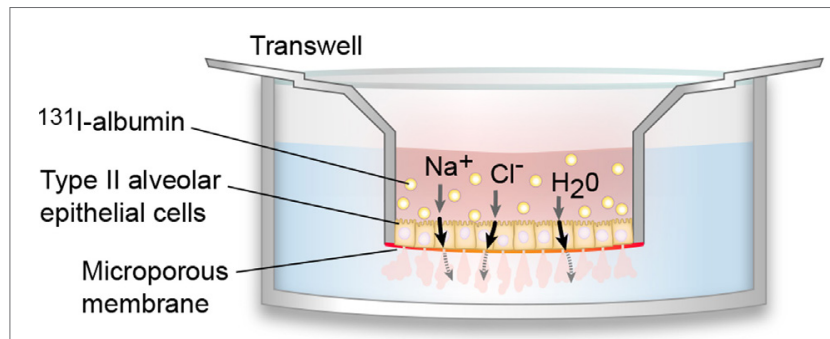

FIGURE 2 | In vitro model of polarized human alveolar type II epithelial cells. In 2006, Fang et al. developed an in vitro model of the polarized human alveolar epithelial surface, which has been used in multiple subsequent studies of alveolar fluid clearance (AFC) (32). To create this model, type II alveolar epithelial cells are isolated from human donor lungs and cultured on a collagen-I coated 24-well plate where they formed tight monolayers. Pulmonary edema fluid (pink), which contains water $\left(\mathrm{H}_{2} \mathrm{O}\right)$, sodium ions $\left(\mathrm{Na}^{+}\right)$, chloride ions $\left(\mathrm{Cl}^{-}\right)$, as well as other ions and proteins, is mixed with ${ }^{131} \mathrm{I}$-albumin (yellow circles) and introduced to the apical compartment. Pulmonary edema fluid is able to cross the alveolar cell monolayer, but ${ }^{131}$-albumin cannot cross, so it is possible to calculate AFC by measuring the change in ${ }^{131} \mathrm{l}$-albumin concentration between the apical and basal compartments. sodium channel (37). These and other studies confirmed that AFC is reduced in lung injury through decreased efficiency of alveolar ion channels as well as altered permeability of the normally tight alveolar epithelium.

\section{MESENCHYMAL STEM (STROMAL) CELLS (MSCS) AS A PROMISING THERAPY FOR ARDS}

The laboratory-based investigations described above significantly advanced our understanding of ARDS pathophysiology, paving the way for targeted molecular therapies to improve the clinical treatment of patients with ARDS. MSCs are one such promising new cell-based therapy, which we will discuss in this section.

Mesenchymal stem (stromal) cells are bone marrow-derived cells that can differentiate in vitro into chondrocytes, osteoblasts, and adipocytes, although they do not have true stem cell properties in vivo (38). MSCs secrete paracrine factors that can decrease inflammation and enhance endothelial and epithelial repair (39). Several groups are studying the therapeutic potential of MSCs in sepsis $(40,41)$, diabetes $(42)$, myocardial infarction (43), hepatic failure (44), and acute renal failure $(45,46)$. It was hypothesized that MSCs might also be beneficial in the treatment of ARDS.

To test this hypothesis, several groups studied whether MSCs could reduce the severity of lung, kidney, and brain injury in preclinical models (47). In 2007, Gupta et al. reported that treatment with MSCs improved survival and reduced pulmonary edema in Escherichia coli endotoxin-induced lung injury in mice (48). Subsequent studies showed that MSCs attenuated lung injury in mice and in ex vivo human lungs injured with live bacteria (49, 50). MSCs also enhance bacterial clearance and improve survival in mouse and rat models of sepsis $(41,51)$, and they have beneficial effects in ventilator-induced acute lung injury (52). Based on this preclinical data, phase 1 and 2 clinical trials are currently testing MSCs as a therapy for ARDS (53).

Given the potential therapeutic benefit of MSCs in the treatment of ARDS, it is important to understand their mechanism of action and several possible mechanisms have been implicated to date. In 2010, Fang et al. used SiRNA knockdown of paracrine soluble factors in the setting of MSC treatment in vitro in cultured human type 2 cells and found that angiopoietin- 1 secretion was partially responsible for the beneficial effect of MSCs (54). Subsequent studies suggested that interleukin-1 receptor antagonist and growth factors such as keratinocyte growth (KGF) factor may also be involved in this process (52). KGF can upregulate AFC in ex vivo human lungs injured by endotoxin (55). A 2015 study demonstrated that lipoxin A4, a pro-resolving lipid mediator, is upregulated in the presence of MSCs, suggesting that this molecule may be important for MSC-mediated resolution of lung injury (56). Other studies indicated that the therapeutic effects of MSCs may also mediate the release of microvesicles, which are involved in cell-cell communication (57) or due to mitochondrial transfer (58). Thus, several mechanisms may explain MSC-mediated resolution of lung injury, and further studies are needed to fully characterize this process. 


\section{DISCUSSION}

The importance of alveolar ion transport in AFC has been established, but further work is needed to better characterize this process. For example, type I alveolar cells participate in apical-basolateral fluid transport $(8,59)$, but there is no suitable cell culture model for type I cells so the physiology of these cells is not as well understood. In addition, sodium transport has been well characterized, but the contribution of transport of other ions is not as clear. Future experiments are needed to clarify the role of type I versus type II alveolar cells and the roles of additional ion channels in alveolar fluid transport.

The in vitro and in vivo models of ARDS have enhanced our understanding of ARDS pathophysiology. Not only are these models useful for the study of ARDS but measurements of AFC and paracellular permeability can also be used to better understand other pulmonary conditions. For example, Chan et al. (60) compared the extent to which avian influenza A (H5N1) virus and seasonal influenza $\mathrm{A}(\mathrm{H} 1 \mathrm{~N} 1)$ virus impair $\mathrm{AFC}$ and protein permeability using the transwell model first used in the ARDS models (60). The authors found that avian influenza A (H5N1) virus causes a more severe reduction in alveolar protein transport than the seasonal influenza A (H1N1) virus, mimicking its greater clinical severity. Future work can use these models to better understand how AFC is affected in other pulmonary pathologies as well.

Preliminary preclinical experiments have suggested that MSCs promote the resolution of alveolar edema fluid. It is possible that

\section{REFERENCES}

1. Staub NC. The pathogenesis of pulmonary edema. Prog Cardiovasc Dis (1980) 23(1):53-80. doi:10.1016/0033-0620(80)90005-5

2. Staub NC. Pulmonary edema due to increased microvascular permeability. Annu Rev Med (1981) 32(1):291-312. doi:10.1146/annurev.me.32.020181. 001451

3. Matthay MA, Folkesson HG, Clerici C. Lung epithelial fluid transport and the resolution of pulmonary edema. Physiol Rev (2002) 82(3):569-600. doi:10.1152/physrev.00003.2002

4. Matthay MA, Ware LB, Zimmerman GA. The acute respiratory distress syndrome. J Clin Invest (2012) 122(8):2731-40. doi:10.1172/JCI60331

5. Ferguson ND, Fan E, Camporota L, Antonelli M, Anzueto A, Beale R, et al. The Berlin definition of ARDS: an expanded rationale, justification, and supplementary material. Intensive Care Med (2012) 38(10):1573-85. doi:10.1007/ s00134-012-2682-1

6. Rubenfeld GD, Caldwell E, Peabody E, Weaver J, Martin DP, Neff M, et al. Incidence and outcomes of acute lung injury. N Engl J Med (2005) 353(16):1685-93. doi:10.1056/NEJMoa050333

7. The Acute Respiratory Distress Syndrome Network. Ventilation with lower tidal volumes as compared with traditional tidal volumes for acute lung injury and the acute respiratory distress syndrome. N Engl J Med (2000) 342:1301-8. doi:10.1056/NEJM200005043421801

8. Johnson MD, Widdicombe JH, Allen L, Barbry P, Dobbs LG. Alveolar epithelial type I cells contain transport proteins and transport sodium, supporting an active role for type I cells in regulation of lung liquid homeostasis. Proc Natl Acad Sci U S A (2002) 99(4):1966-71. doi:10.1073/pnas.042689399

9. Canessa CM, Schild L, Buell G, Thorens B, Gautschi I, Horisberger JD, et al. Amiloride-sensitive epithelial $\mathrm{Na}+$ channel is made of three homologous subunits. Nature (1994) 367(6462):463-7. doi:10.1038/367463a0

10. Matalon S, O'Brodovich H. Sodium channels in alveolar epithelial cells: molecular characterization, biophysical properties, and physiological
MSCs act directly on alveolar ion channels via cell-cell interactions or indirectly via paracrine factors; future experiments are needed to clarify their mechanism of action in the lung. If MSCs indeed promote $\mathrm{AFC}$, they may serve as a promising cell-based therapy for ARDS.

\section{SUMMARY}

In this review, we have discussed how vectorial ion channels in alveolar epithelium generate an osmotic gradient that drives AFC in both physiologic and pathologic conditions. Both AFC and paracellular permeability can be measured using in vitro and in vivo models of ARDS, and these studies indicate that vectorial ion transport is less effective in injured lungs than in uninjured lungs. Recent studies suggest that MSCs interact with alveolar epithelium and ion channels to increase AFC and thus may serve as a promising treatment for ARDS.

\section{AUTHOR CONTRIBUTIONS}

LH and MM composed this mini-review manuscript together. $\mathrm{LH}$ is the first author.

\section{ACKNOWLEDGMENTS}

This work was supported by National Heart, Lung, and Blood Institute (NHLBIR37HL51856 and NHLBIU01HL1230004). The authors thank Diana Lim for creating the figures for this article. significance. Annu Rev Physiol (1999) 61(1):627-61. doi:10.1146/annurev. physiol.61.1.627

11. Fang X, Fukuda N, Barbry P, Sartori C, Verkman AS, Matthay MA. Novel role for CFTR in fluid absorption from the distal airspaces of the lung. J Gen Physiol (2002) 119(2):199-208. doi:10.1085/jgp.119.2.199

12. Verkman AS, Matthay MA, Song Y. Aquaporin water channels and lung physiology. Am J Physiol Lung Cell Mol Physiol (2000) 278(5):L867-79.

13. Eaton DC, Chen J, Ramosevac S, Matalon S, Jain L. Regulation of $\mathrm{Na}+$ channels in lung alveolar type II epithelial cells. Proc Am Thorac Soc (2004) 1(1):10-6. doi:10.1513/pats.2306008

14. Mutlu GM, Sznajder JI. Mechanisms of pulmonary edema clearance. Am J Physiol Lung Cell Mol Physiol (2005) 289(5):L685-95. doi:10.1152/ ajplung.00247.2005

15. Matthay MA, Wiener-Kronish JP. Intact epithelial barrier function is critical for the resolution of alveolar edema in humans. Am Rev Respir Dis (1990) 142(6,1):1250-7.doi:10.1164/ajrccm/142.6_Pt_1.1250

16. Ware LB, Matthay MA. Alveolar fluid clearance is impaired in the majority of patients with acute lung injury and the acute respiratory distress syndrome. Am J Respir Crit Care Med (2001) 163(6):1376-83. doi:10.1164/ ajrccm.163.6.2004035

17. Vivona ML, Matthay M, Chabaud MB, Friedlander G, Clerici C. Hypoxia reduces alveolar epithelial sodium and fluid transport in rats: reversal by $\beta$-adrenergic agonist treatment. Am J Respir Cell Mol Biol (2001) 25(5):554-61. doi:10.1165/ajrcmb.25.5.4420

18. Vadász I, Raviv S, Sznajder JI. Alveolar epithelium and Na, K-ATPase in acute lung injury. Intensive Care Med (2007) 33(7):1243-51. doi:10.1007/ s00134-007-0661-8

19. Briva A, Vadász I, Lecuona E, Welch LC, Chen J, Dada LA, et al. High CO2 levels impair alveolar epithelial function independently of $\mathrm{pH}$. PLoS One (2007) 2(11):e1238. doi:10.1371/journal.pone.0001238

20. Frank JA, Gutierrez JA, Jones KD, Allen L, Dobbs L, Matthay MA. Low tidal volume reduces epithelial and endothelial injury in acid-injured rat lungs. 
Am J Respir Crit Care Med (2002) 165(2):242-9. doi:10.1164/ajrccm.165.2. 2108087

21. Amato MBP, Barbas CSV, Medeiros DM, Laffey JG, Engelberts D, Kavanagh BP. Ventilation with lower tidal volumes as compared with traditional tidal volumes for acute lung injury. N Engl J Med (2000) 343(2000):812-4. doi:10.1056/NEJM200009143431113

22. Schuller D, Schuster DP. Fluid-management strategies in acute lung injury. $N$ Engl J Med (2006) 355(11):1175. doi:10.1056/NEJMc061857

23. Pugin J, Verghese G, Widmer MC, Matthay MA. The alveolar space is the site of intense inflammatory and profibrotic reactions in the early phase of acute respiratory distress syndrome. Crit Care Med (1999) 27(2):304-12. doi:10.1097/00003246-199902000-00036

24. Olman MA, White KE, Ware LB, Simmons WL, Benveniste EN, Zhu S, et al. Pulmonary edema fluid from patients with early lung injury stimulates fibroblast proliferation through IL-1 $\beta$-induced IL-6 expression. J Immunol (2004) 172(4):2668-77. doi:10.4049/jimmunol.172.4.2668

25. Ware LB, Matthay MA. The acute respiratory distress syndrome. $N$ Engl J Med (2000) 342(18):1334-49. doi:10.1056/NEJM200005043421806

26. Fukuda N, Jayr C, Lazrak A, Wang Y, Lucas R, Matalon S, et al. Mechanisms of TNF- $\alpha$ stimulation of amiloride-sensitive sodium transport across alveolar epithelium. Am J Physiol Lung Cell Mol Physiol (2001) 280(6):L1258-65.

27. Elia N, Tapponnier M, Matthay MA, Hamacher J, Pache JC, Bründler MA, et al. Functional identification of the alveolar edema reabsorption activity of murine tumor necrosis factor- $\alpha$. Am J Respir Crit Care Med (2003) 168(9):1043-50. doi:10.1164/rccm.200206-618OC

28. Dagenais A, Fréchette R, Yamagata Y, Yamagata T, Carmel JF, Clermont ME, et al. Downregulation of ENaC activity and expression by TNF- $\alpha$ in alveolar epithelial cells. Am J Physiol Lung Cell Mol Physiol (2004) 286(2):L301-11. doi:10.1152/ajplung.00326.2002

29. Roux J, Kawakatsu H, Gartland B, Pespeni M, Sheppard D, Matthay $\mathrm{MA}$, et al. Interleukin-1 $\beta$ decreases expression of the epithelial sodium channel $\alpha$-subunit in alveolar epithelial cells via a p38 MAPK-dependent signaling pathway. J Biol Chem (2005) 280(19):18579-89. doi:10.1074/jbc. M410561200

30. Hung CF, Mittelsteadt KL, Brauer R, McKinney BL, Hallstrand TS, Parks WC, et al. Lung pericyte-like cells are functional immune sentinel cells. Am J Physiol Lung Cell Mol Physiol (2017) 10:ajlung.00349.2016. doi:10.1152/ ajplung.00349.2016

31. Parsons PE, Eisner MD, Thompson BT, Matthay MA, Ancukiewicz M, Bernard GR, et al. Lower tidal volume ventilation and plasma cytokine markers of inflammation in patients with acute lung injury. Crit Care Med (2005) 33(1):1-6. doi:10.1097/01.CCM.0000149854.61192.DC

32. Fang X, Song Y, Hirsch J, Galietta LJ, Pedemonte N, Zemans RL, et al. Contribution of CFTR to apical-basolateral fluid transport in cultured human alveolar epithelial type II cells. Am J Physiol Lung Cell Mol Physiol (2006) 290(2):L242-9. doi:10.1152/ajplung.00178.2005

33. Lee JW, Fang X, Dolganov G, Fremont RD, Bastarache JA, Ware LB, et al. Acute lung injury edema fluid decreases net fluid transport across human alveolar epithelial type II cells. J Biol Chem (2007) 282(33):24109-19. doi:10.1074/jbc. M700821200

34. Zemans RL, Colgan SP, Downey GP. Transepithelial migration of neutrophils: mechanisms and implications for acute lung injury. Am J Respir Cell Mol Biol (2009) 40(5):519-35. doi:10.1165/rcmb.2008-0348TR

35. Calfee CS, Matthay MA. Clinical immunology: culprits with evolutionary ties. Nature (2010) 464(7285):41-2. doi:10.1038/464041a

36. Kurahashi K, Kajikawa O, Sawa T, Ohara M, Gropper MA, Frank DW, et al. Pathogenesis of septic shock in Pseudomonas aeruginosa pneumonia. J Clin Invest (1999) 104(6):743-50. doi:10.1172/JCI7124

37. Chen XJ, Seth S, Yue G, Kamat P, Compans RW, Guidot D, et al. Influenza virus inhibits ENaC and lung fluid clearance. Am J Physiol Lung Cell Mol Physiol (2004) 287(2):L366-73. doi:10.1152/ajplung.00011.2004

38. Friedenstein AJ, Petrakova KV, Kurolesova AI, Frolova GP. Hetertrohic transplants of bone marrow. Transplantation (1968) 6(2):230-47. doi:10.1097/00007890-196803000-00009

39. Parekkadan B, Milwid JM. Mesenchymal stem cells as therapeutics. Annu Rev Biomed Eng (2010) 12:87. doi:10.1146/annurev-bioeng-070909-105309

40. Németh K, Leelahavanichkul A, Yuen PS, Mayer B, Parmelee A, Doi K, et al. Bone marrow stromal cells attenuate sepsis via prostaglandin E2-dependent reprogramming of host macrophages to increase their interleukin-10 production. Nat Med (2009) 15(1):42-9. doi:10.1038/nm.1905

41. Mei SH, Haitsma JJ, Dos Santos CC, Deng Y, Lai PF, Slutsky AS, et al. Mesenchymal stem cells reduce inflammation while enhancing bacterial clearance and improving survival in sepsis. Am J Respir Crit Care Med (2010) 182(8):1047-57. doi:10.1164/rccm.201001-0010OC

42. Lee RH, Seo MJ, Reger RL, Spees JL, Pulin AA, Olson SD, et al. Multipotent stromal cells from human marrow home to and promote repair of pancreatic islets and renal glomeruli in diabetic NOD/scid mice. Proc Natl Acad Sci U S A (2006) 103(46):17438-43. doi:10.1073/pnas.0608249103

43. Li TS, Hayashi M, Ito H, Furutani A, Murata T, Matsuzaki M, et al. Regeneration of infarcted myocardium by intramyocardial implantation of ex vivo transforming growth factor- $\beta$-preprogrammed bone marrow stem cells. Circulation (2005) 111(19):2438-45. doi:10.1161/01.CIR.0000167553.49133.81

44. Parekkadan B, Van Poll D, Suganuma K, Carter EA, Berthiaume F, Tilles AW, et al. Mesenchymal stem cell-derived molecules reverse fulminant hepatic failure. PLoS One (2007) 2(9):e941. doi:10.1371/journal.pone.0000941

45. Tögel $\mathrm{F}, \mathrm{Hu} \mathrm{Z}$, Weiss $\mathrm{K}$, Isaac J, Lange $\mathrm{C}$, Westenfelder $\mathrm{C}$. Administered mesenchymal stem cells protect against ischemic acute renal failure through differentiation-independent mechanisms. Am J Physiol Renal Physiol (2005) 289(1):F31-42. doi:10.1152/ajprenal.00007.2005

46. Ullah I, Subbarao RB, Rho GJ. Human mesenchymal stem cells-current trends and future prospective. Biosci Rep (2015) 35(2):e00191. doi:10.1042/ BSR20150025

47. Matthay MA, Pati S, Lee JW. Mesenchymal stem (stromal) cells: biology and preclinical evidence for therapeutic potential for organ dysfunction following trauma or sepsis. Stem Cells (2017) 35:316-24. doi:10.1002/stem.2551

48. Gupta N, Su X, Popov B, Lee JW, Serikov V, Matthay MA. Intrapulmonary delivery of bone marrow-derived mesenchymal stem cells improves survival and attenuates endotoxin-induced acute lung injury in mice. JImmunol (2007) 179(3):1855-63. doi:10.4049/jimmunol.179.3.1855

49. Gupta N, Krasnodembskaya A, Kapetanaki M, Mouded M, Tan X, Serikov $\mathrm{V}$, et al. Mesenchymal stem cells enhance survival and bacterial clearance in murine Escherichia coli pneumonia. Thorax (2012) 67(6):533-9. doi:10.1136/ thoraxjnl-2011-201176

50. Lee JW, Krasnodembskaya A, McKenna DH, Song Y, Abbott J, Matthay MA. Therapeutic effects of human mesenchymal stem cells in ex vivo human lungs injured with live bacteria. Am J Respir Crit Care Med (2013) 187(7):751-60. doi:10.1164/rccm.201206-0990OC

51. Devaney J, Horie S, Masterson C, Elliman S, Barry F, O'Brien T, et al. Human mesenchymal stromal cells decrease the severity of acute lung injury induced by E. coli in the rat. Thorax (2015) 70(7):625-35. doi:10.1136/ thoraxjnl-2015-206813

52. Walter J, Ware LB, Matthay MA. Mesenchymal stem cells: mechanisms of potential therapeutic benefit in ARDS and sepsis. Lancet Respir Med (2014) 2(12):1016-26. doi:10.1016/S2213-2600(14)70217-6

53. Wilson JG, Liu KD, Zhuo H, Caballero L, McMillan M, Fang X, et al. Mesenchymal stem (stromal) cells for treatment of ARDS: a phase 1 clinical trial. Lancet Respir Med (2015) 3(1):24-32. doi:10.1016/S2213-2600(14) 70291-7

54. Fang X, Neyrinck AP, Matthay MA, Lee JW. Allogeneic human mesenchymal stem cells restore epithelial protein permeability in cultured human alveolar type II cells by secretion of angiopoietin-1.J Biol Chem (2010) 285(34):2621122. doi:10.1074/jbc.M110.119917

55. Lee JW, Fang X, Gupta N, Serikov V, Matthay MA. Allogeneic human mesenchymal stem cells for treatment of $E$. coli endotoxin-induced acute lung injury in the ex vivo perfused human lung. Proc Natl Acad Sci U S A (2009) 106(38):16357-62. doi:10.1073/pnas.0907996106

56. Fang X, Abbott J, Cheng L, Colby JK, Lee JW, Levy BD, et al. Human mesenchymal stem (stromal) cells promote the resolution of acute lung injury in part through lipoxin A4. J Immunol (2015) 195(3):875-81. doi:10.4049/ jimmunol.1500244

57. Zhu YG, Feng XM, Abbott J, Fang XH, Hao Q, Monsel A, et al. Human mesenchymal stem cell microvesicles for treatment of Escherichia coli endotoxin-induced acute lung injury in mice. Stem Cells (2014) 32(1):116-25. doi:10.1002/stem.1504

58. Islam MN, Das SR, Emin MT, Wei M, Sun L, Westphalen $\mathrm{K}$, et al. Mitochondrial transfer from bone-marrow-derived stromal cells to pulmonary 
alveoli protects against acute lung injury. Nat Med (2012) 18(5):759-65. doi:10.1038/ nm.2736

59. Ridge KM, Olivera WG, Saldias F, Azzam Z, Horowitz S, Rutschman DH, et al. Alveolar type 1 cells express the $\alpha 2 \mathrm{Na}$, K-ATPase, which contributes to lung liquid clearance. Circ Res (2003) 92(4):453-60. doi:10.1161/01.RES.0000059414. 10360.F2

60. Chan MC, Kuok DI, Leung CY, Hui KP, Valkenburg SA, Lau EH, et al. Human mesenchymal stromal cells reduce influenza A H5N1-associated acute lung injury in vitro and in vivo. Proc Natl Acad Sci U S A (2016) 113(13):3621-6. doi:10.1073/pnas.1601911113
Conflict of Interest Statement: The authors declare that the research was conducted in the absence of any commercial or financial relationships that could be construed as a potential conflict of interest.

Copyright $\odot 2017$ Huppert and Matthay. This is an open-access article distributed under the terms of the Creative Commons Attribution License (CC BY). The use, distribution or reproduction in other forums is permitted, provided the original author(s) or licensor are credited and that the original publication in this journal is cited, in accordance with accepted academic practice. No use, distribution or reproduction is permitted which does not comply with these terms. 